\title{
Ecological aspects of a population of Phrynops geoffroanus (Schweigger, 1812) in a semi-arid area of Northeastern Brazil
}

\author{
Aspectos ecológicos de uma população de Phrynops geoffroanus (Schweigger, 1812) em uma área \\ semiárida do Nordeste do Brasil \\ Aspectos ecológicos de una población de Phrynops geoffroanus (Schweigger, 1812) en una zona \\ semiárida del nordeste de Brasil
}

Received: 04/17/2021 | Reviewed: 04/25/2021 | Accept: 06/01/2021 | Published: 06/14/2021

Marcela Meira Ramos Abrantes ORCID: https://orcid.org/0000-0001-6786-0425 Universidade Federal Rural de Pernambuco, Brazil E-mail: marcelabio@gmail.com Jéssica Araújo Pereira ORCID: https://orcid.org/0000-0002-9600-6858 Universidade Federal de Campina Grande, Brazil E-mail: jessicaa_araujo13@hotmail.com Arthur Willian de Lima Brasil ORCID: https://orcid.org/0000-0002-1862-6517 Universidade Federal da Paraíba, Brazil E-mail: arthurwillian7@yahoo.com.br Aline Raiane de Souza ORCID: https://orcid.org/0000-0001-5122-1864 Universidade Federal de Campina Grande, Brazil E-mail: alinebio1105@gmail.com

Danielly Fernanda de Assis Dantas ORCID: https://orcid.org/0000-0003-1193-9497 Universidade Federal de Campina Grande, Brazil

E-mail: daniellyfernanda.ufcg@gmail.com

Paulo Henrique Izidro de Brito ORCID: https://orcid.org/0000-0002-9986-7557 Universidade Federal de Campina Grande, Brazil Email: paulo.britoing@gmail.com

Stephenson Hallison Formiga Abrantes ORCID: https://orcid.org/0000-0001-5727-8781 Universidade Federal de Campina Grande, Brazil

E-mail: stephesonabrantes@yahoo.com.br Daniel Lopes Araújo ORCID: https://orcid.org/0000-0002-1625-0368 Universidade Federal de Pernambuco, Brazil E-mail: lopes.araujo@ufpe.br

Geraldo Jorge Barbosa de Moura ORCID: https://orcid.org/0000-0001-7241-7524 Universidade Federal Rural de Pernambuco, Brazil E-mail: geraldojbm@gmail.com

\begin{abstract}
Phrynops geoffroanus is a testudine of the family Chelidae that has a wide distribution. However, there are gaps in the knowledge of its biology. This study aimed to characterize demographically and morphometrically a population of Phrynops geoffroanus in an ephemeral water reservoir in a semi-arid area of Paraíba, in the period from April 2016 to March 2017. The individuals were captured manually and by hoop-net trap. Data on size distribution were described by mean and standard deviation. Size and weight were compared between sexes and capture methods using a MANOVA. Sex ratio was compared between capture methods using Pearson's chi-squared test. Population density and biomass were calculated. The number of animals captured was grouped into two shifts and compared. Throughout the year, 113 individuals of $P$. geoffroanus were captured in the reservoir, with a population of $43.4 \%$ males, $47.8 \%$ females and $8.8 \%$ juveniles, with a density of at least 41.8 individuals / ha and biomass of $33.05 \mathrm{~kg} / \mathrm{ha}$. There is no significant relationship between the amount of animals captured and the amount of rainfall during the period sampled. Due mainly to the ephemerality of the aquatic environments of the Caatinga and the unpredictability of rainfall in this
\end{abstract}


biome, the populations of aquatic species show large variations in population and in their biological activities. Further studies are needed to fill several gaps in the knowledge of the natural history of Caatinga testudines.

Keywords: Geoffroy's side-necked turtle; Morphometry; Sexual dimorphism; Demography.

\section{Resumo}

Phrynops geoffroanus é um testudine da família Chelidae que possui uma ampla distribuição. No entanto, existem lacunas no conhecimento de sua biologia. Este estudo teve como objetivo caracterizar demográfica e morfometricamente uma população de Phrynops geoffroanus em um reservatório de água efêmero em uma área semiárida da Paraíba, no período de abril de 2016 a março de 2017. Os indivíduos foram capturados manualmente e por armadilha denominada "covo". Os dados sobre a distribuição do tamanho foram descritos por média e desvio padrão. O tamanho e o peso foram comparados entre os sexos e os métodos de captura usando uma MANOVA. A proporção sexual foi comparada entre os métodos de captura usando o teste Qui-quadrado de Pearson. A densidade populacional e a biomassa foram calculadas. O número de animais capturados foi agrupado em dois turnos e comparado. Ao longo do ano, foram capturados 113 indivíduos de $P$. geoffroanus no reservatório, com população de 43,4\% machos, 47,8\% fêmeas e 8,8\% de juvenis, com densidade de pelo menos 41,8 indivíduos / ha e biomassa de $33,05 \mathrm{~kg} /$ ha. Não há relação significativa entre a quantidade de animais capturados e a quantidade de chuva durante o período amostrado. Devido principalmente à efemeridade dos ambientes aquáticos da Caatinga e à imprevisibilidade das chuvas desse bioma, as populações de espécies aquáticas apresentam grandes variações populacionais e em suas atividades biológicas. Outros estudos são necessários para preencher várias lacunas no conhecimento da história natural dos testudines da Caatinga.

Palavras-chave: Cágado-de-barbicha; Morfometria; Dimorfismo sexual; Demografia.

\section{Resumen}

Phrynops geoffroanus es un testudino de la familia Chelidae que tiene una amplia distribución. Sin embargo, existen lagunas en el conocimiento de su biología. Este estudio tuvo como objetivo caracterizar demográfica y morfométricamente una población de Phrynops geoffroanus en un embalse de agua efímera en una zona semiárida de Paraíba, desde abril de 2016 hasta marzo de 2017. Los individuos fueron capturados manualmente y mediante una trampa llamada "covo". Los datos sobre la distribución del tamaño se describieron mediante la media y la desviación estándar. La talla y el peso se compararon entre sexos y métodos de captura mediante un MANOVA. La proporción de sexos se comparó entre los métodos de captura mediante la prueba de chi-cuadrado de Pearson. Se calculó la densidad de población y la biomasa. El número de animales capturados se agrupó en dos turnos y se comparó. Fueron capturados 113 individuos de $P$. geoffroannus en el embalse, 43,4\% de machos, 47,8\% de hembras y 8,8\% de juveniles, con una densidad de al menos 41,8 individuos $/$ ha y una biomasa de $33,05 \mathrm{~kg} / \mathrm{ha}$. No existe una relación significativa entre la cantidad de animales capturados y la cantidad de precipitaciones durante el periodo muestreado. Debido principalmente a lo efímero de los medios acuáticos de la Caatinga y a la imprevisibilidad de las precipitaciones en este bioma, las poblaciones de especies acuáticas presentan grandes variaciones poblacionales y en sus actividades biológicas. Se necesitan más estudios para llenar varias lagunas en el conocimiento de la historia natural de los testudines de Caatinga.

Palabras clave: Tortuga; Morfometría; Dimorfismo sexual; Demografía.

\section{Introduction}

Studies on the population structure of any taxon play an important role in establishing species conservation strategies (Primack, 2012). Thus, information on population structure and population size of turtles are tools to assess the status of various populations (Brito et al., 2009). However, some aspects of turtle life history, such as late sexual maturity and long life cycles, make it difficult to understand their population dynamics (Rueda-Almonacid et al., 2007).

Although these studies are important, there are few studies dealing with Caatinga testudine species (Moura et al., 2014; Moura et al., 2015; Rodrigues \& Silva, 2015), unlike chelonian species from other regions of Brazil (Fachín-Terán et al., 2003, 2004; Batistella et al., 2008; Brito et al., 2009; Miorando et al., 2015). This biome, which occupies much of northeastern Brazil, is characterized by remarkable seasonality, featuring a prolonged dry season and an extremely irregular rainy season (Moro et al., 2016). As the activity patterns of chelonians are directly associated with precipitation rates and air temperature (Souza, 2004), this irregularity in Caatinga rainfall patterns directly affects the behavior and the way species interact with this environment, thus generating different patterns associated with the geographic distribution of species (Souza \& Molina, 2007).

Phrynops geoffroanus (Schweigger, 1812) is a species of the family Chelidae, popularly known as the Brazilian 
terrapin, has a wide distribution, occurring in the most diverse environments, with influence from the Cerrado, Amazon Rainforest, Caatinga and even highly anthropized and polluted environments (Ferrara et al, 2017). This wide distribution has generated a number of gaps in the knowledge of the biology of this species; it is not known, for example, how this wide distribution may be influencing body size patterns, or even litter size (Souza \& Molina, 2007). Associated with this lack of knowledge, Costa-Neto \& Alves (2010) report the use of this species for medicinal purposes by some communities in Northeastern Brazil and this species is also used as a food resource by local populations in Paraíba State (Alves et al., 2002).

Due to the lack of knowledge about the population patterns of $P$. geoffroanus in Caatinga, the objective of this study was to describe the morphological aspects, population structure and density, activity patterns and sex ratio of $P$. geoffroanus in a Caatinga ephemeral water reservoir in a semi-arid region of Paraíba.

\section{Methodology}

\subsection{Study Area}

The study was carried out in an area of Caatinga in the interior of the Depression of the State of Paraíba, in the Fazenda Tamanduá Private Natural Heritage Reserve (RPPN) (Figure 1). Fazenda Tamanduá (-7.011111S and -36.369444W) has a total area of 3,073 ha, with predominantly dense shrubby-arboreal caatinga vegetation (Passos Filho et al., 2015) in good condition, and the predominant soils are eutrophic litholitic with rocky outcrops (Embrapa, 2006). The climate is characteristic of semi-arid tropical regions (BSh), with low annual rainfall, concentrated in a short period of time (January to May), followed by a long period of drought.

The individuals were collected from an ephemeral reservoir used to supply the farm's cattle herd. This reservoir has a total area of $27,352 \mathrm{~m}^{2}$ (27.35 ha). The vegetation at the edge of the reservoir is composed of shrubs and aquatic plants.

Figure 1. Geographic location of Fazenda Tamanduá, in the municipality of Santa Terezinha, microregion of Patos-PB.
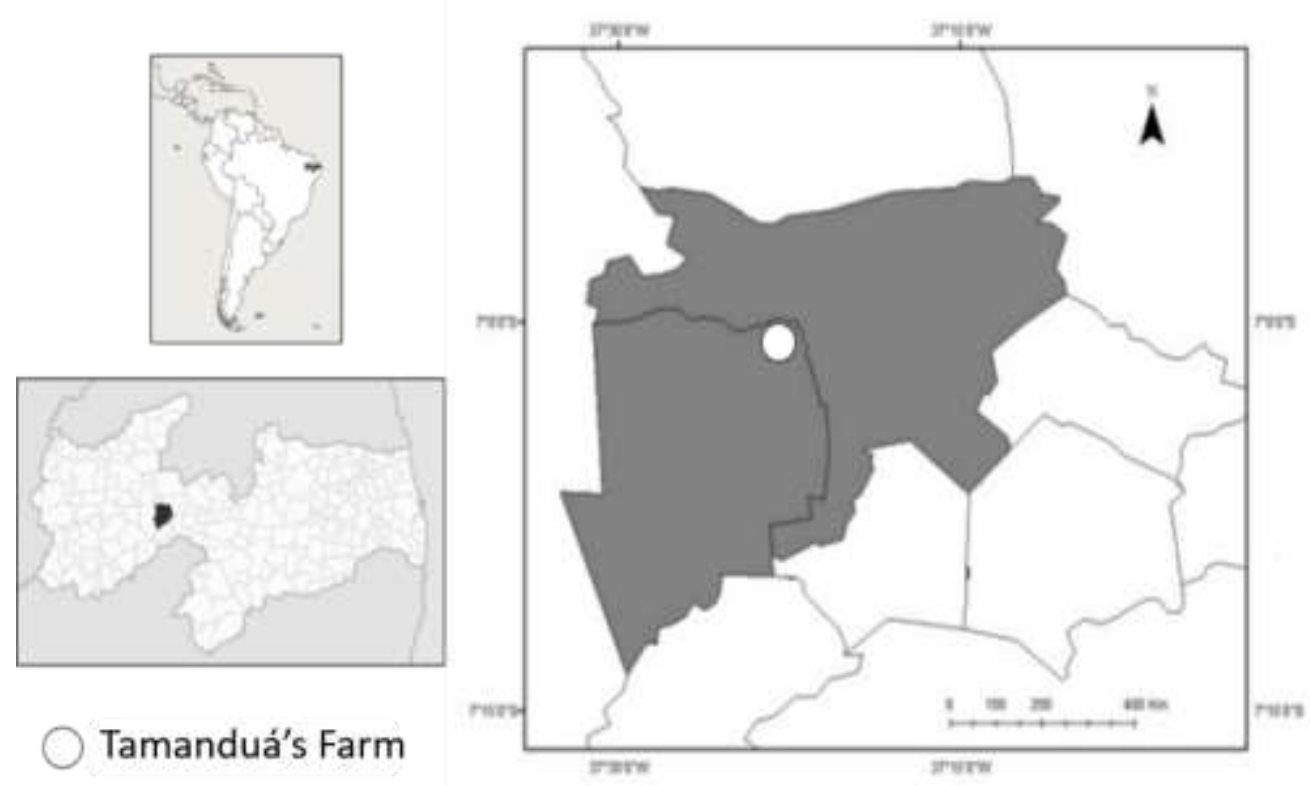

Source: Survey data (2017). 


\subsection{Methodological Procedures}

Specimens were captured from April 2016 to March 2017, with monthly expeditions, during 48 hours each. The turtles were captured manually and using a hoop-net trap. These traps were placed on the banks of the reservoir and arranged submerged, and meat and/or fish were used as bait. The traps were reviewed daily, with a 4-hour interval between each review, remaining in the water during the entire sampling period.

Each captured specimen was weighed and some measurements were taken: Carapace length (MCL); Carapace width (MCW); Head width (HW); Head length (HL); Mouth width (MW); Plastron width (MPW); Plastron length (MPL); Distance between the base of the tail and the cloaca (DTC); Anal plastron plate opening (AAP); Carapace curvilinear length (CCL) and carapace curvilinear width $(\mathrm{CCW})$ were obtained using a plastic measuring tape on a millimeter scale. Captured animals were marked according to the method suggested by Cagle (1939) and had the sexes identified according to secondary sexual characteristics such as tail length and plastron concavity (Martins \& Souza, 2008; Brito et al., 2009; Forero-Medina et al., 2013; Marques et al., 2013; Moura et al., 2015; Santana et al., 2012; Santana et al., 2016; Perry \& Mitchell, 2016). We considered as adults individuals with more than $120 \mathrm{~mm}$ of LCM (Santana et al., 2012), individuals that did not show evident secondary sexual characteristics were considered juveniles.

All animal procedures were performed according to international care practices, under the control of the Internal Ethics Committee of the Federal University of Campina Grande (CEUA-UFCG 100/2016). It was also authorized by the Brazilian Institute of the Environment (ICMBIO / SISBIO, No. 53670-1).

\subsection{Data Analysis}

Data on size distribution (length and width) of males, females and juveniles were described by mean and standard deviation. Morphometric characteristics were compared between sexes using a MANOVA test to identify possible differences between adult males and females. Sex ratio was compared between capture methods using Pearson's Chi-squared Test (Zar, 2010). Population density was calculated using the total number of individuals collected divided by the total area of the reservoir. Biomass was calculated by summing the mass values of all individuals collected divided by the total area of the reservoir. To identify in which period of the day specimens were captured more, the number of animals captured was grouped in two shifts (6 am to $5.59 \mathrm{pm}$ and $6 \mathrm{pm}$ to $5.59 \mathrm{am}$ ) compared between shifts and sexes using a two-factor ANOVA (using only specimens captured by the Covo trap).

To assess the relationship between precipitation and captures and recaptures, a simple linear regression. Pearson's Chisquare tests, as well as PCA, regression analysis and T-test were performed in Past 3.26b software. Two-way ANOVA and MANOVA were performed in SPSS. All tests were performed using covo bay trap of captured specimens.

\section{Results and Discussion}

A total of 113 individuals of $P$. geofroannus were captured in the reservoir throughout the year, with a population size of $43.4 \%$ males ( $n=49), 47.8 \%$ females $(n=54)$ and $8.8 \%$ juveniles $(n=10)$ (Table 1). Of the total, 47 were captured manually, buried in the mud on the banks of the reservoir as it was drying out. However, the sampling methods used did not influence the sex or CML of the captured individuals (Willk's Lambda $=0.985 ; \mathrm{F}_{(4,90)}=0.759 ; \mathrm{p}=0.471$ ).

Regarding sexual dimorphism, MANOVA showed that there is an effect of sex on the size and weight of captured

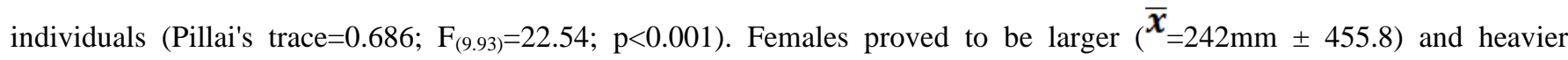

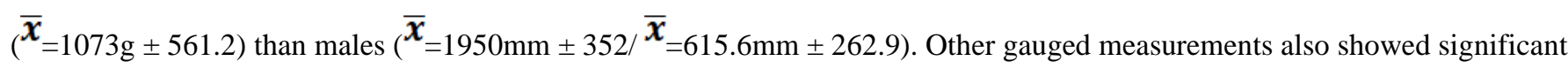


difference between males and females, such as MCW, MPW, MPL, DTC, AAP, CCL and CCW (Table 1). The maximum carapace length (MCL) of the studied population showed normal distribution for females, with more frequent sizes in the classes between 210 and $270 \mathrm{~mm}$ (Figure 2). Although, when observed in isolation, males did not show a normal distribution, the highest frequencies were recorded between 180 and $240 \mathrm{~mm}$.

Table 1. Mean, standard deviation, minimum and maximum for mass (in grams) and each of the morphometric measurements (in millimeters) of adult and juvenile individuals of Phrynops geoffroanus at Fazenda Tamanduá, PB-Brazil. Measurements: Carapace length (MCL); Carapace width (MCW); Head width (HW); Head length (HL); Mouth width (MW); Plastron width (MPW); Plastron length (MPL); Distance between tail base and cloaca (DTC); Plastron anal plate opening (AAP); Curvilinear carapace length (CCL) and curvilinear carapace width (CCW).

\begin{tabular}{|c|c|c|c|c|c|c|}
\hline \multirow[t]{2}{*}{ Variables } & \multicolumn{2}{|l|}{ Males $(n=49)$} & \multicolumn{2}{|l|}{ Females $(n=54)$} & \multicolumn{2}{|c|}{ Juveniles $(\mathrm{n}=10)$} \\
\hline & $\bar{x} \pm \mathrm{dp}$ & Min-Max & $\bar{x} \pm \mathrm{dp}$ & Min-Max & $\bar{x} \pm \mathrm{dp}$ & Min-Max \\
\hline Weight & $615,61 \pm 262,96$ & $155-1250$ & $1073,11 \pm 561,29$ & $175,0-2865,0$ & $114,50 \pm 28,52$ & $80,0-114,5$ \\
\hline MCL & $195,08 \pm 35,20$ & $123,6-258.7$ & $224,25 \pm 45,59$ & $123,7-319,2$ & $102,60 \pm 9,02$ & $93,1-117,2$ \\
\hline MCW & $144 \pm 23,03$ & $100,7-191,5$ & $167,33 \pm 32,68$ & $97,1-250,0$ & $84,54 \pm 6,85$ & $76,3-94,2$ \\
\hline HW & $35,05 \pm 6,21$ & $22,2-57,0$ & $41,83 \pm 9,49$ & $24,3-86,1$ & $20,98 \pm 1,56$ & $18,3-23,6$ \\
\hline HL & $51,06 \pm 7,89$ & $34,9-64,6$ & $59,33 \pm 11,54$ & $31,2-85,0$ & $33,10 \pm 4,52$ & $27,7-39,3$ \\
\hline MW & $27,40 \pm 4,57$ & $17,6-35,4$ & $33,07 \pm 6,49$ & $18,9-47,3$ & $16,03 \pm 1,82$ & $12,2-18,2$ \\
\hline MPW & $110,68 \pm 16,97$ & $76,1-135,2$ & $127,80 \pm 28,29$ & $36,4-188,3$ & $63,43 \pm 5,75$ & $57,2-72,9$ \\
\hline $\mathbf{A A P}$ & $38,59 \pm 11,17$ & $4,23-81,4$ & $42,78 \pm 9,22$ & $19,9-58,7$ & $17,85 \pm 1,45$ & $15,5-20,0$ \\
\hline MPL & $168,28 \pm 28,70$ & $105,5-217,3$ & $192,66 \pm 41,27$ & $107,5-282,6$ & $90,18 \pm 9,12$ & $78,0-103,9$ \\
\hline DTC & $35,12 \pm 10,66$ & $10,8-56,7$ & $23,9 \pm 7,5$ & $7,7-37,0$ & $10,64 \pm 2,97$ & $6,7-16,1$ \\
\hline CCL & $213,84 \pm 32,99$ & $135,0-266,0$ & $244,74 \pm 50,49$ & $134,0-370,0$ & $123,50 \pm 7,69$ & $115,0-136,0$ \\
\hline $\mathrm{CCW}$ & $169,55 \pm 23,82$ & $120,0-216,0$ & $200,0 \pm 41,01$ & $115,0-310,0$ & $108,70 \pm 8,29$ & $100,0-122,0$ \\
\hline
\end{tabular}

Source: Research data (2017).

The sex ratio observed among adults was $1.1(\widehat{O})$ : $1($ ( $)(\mathrm{P}=0.693$; Chi2 $=0.243)$, with no significant difference between the number of females and males. The studied area showed density of $P$. geoffroanus of 41.8 individuals / ha and biomass of $33.05 \mathrm{~kg} / \mathrm{ha}$. Of the individuals captured, 66 were caught in the hoop-net trap, while 47 were caught manually, buried in the mud. There is no significant relationship between the amount of animals caught and the amount of rainfall $\left(\mathrm{R}^{2}=-\right.$ 0.09; $\mathrm{F}=0.0016 ; \mathrm{p}=0.97$ ) during the period sampled (Figure 3).

Regarding the time of capture, there was no significant difference between individuals (total or by classes) captured during the day (from 6 am to $5.59 \mathrm{pm}$ ) or at night (6 pm to $5.59 \mathrm{am}$ ) (Figure 4). 
Figure 3. Number of monthly captures of females, males and juveniles of Phrynops geoffroanus, compared to rainfall indices. Data collected at Fazenda Tamanduá, Santa Terezinha - PB, between August 2016 and March 2017 (recaptures included).

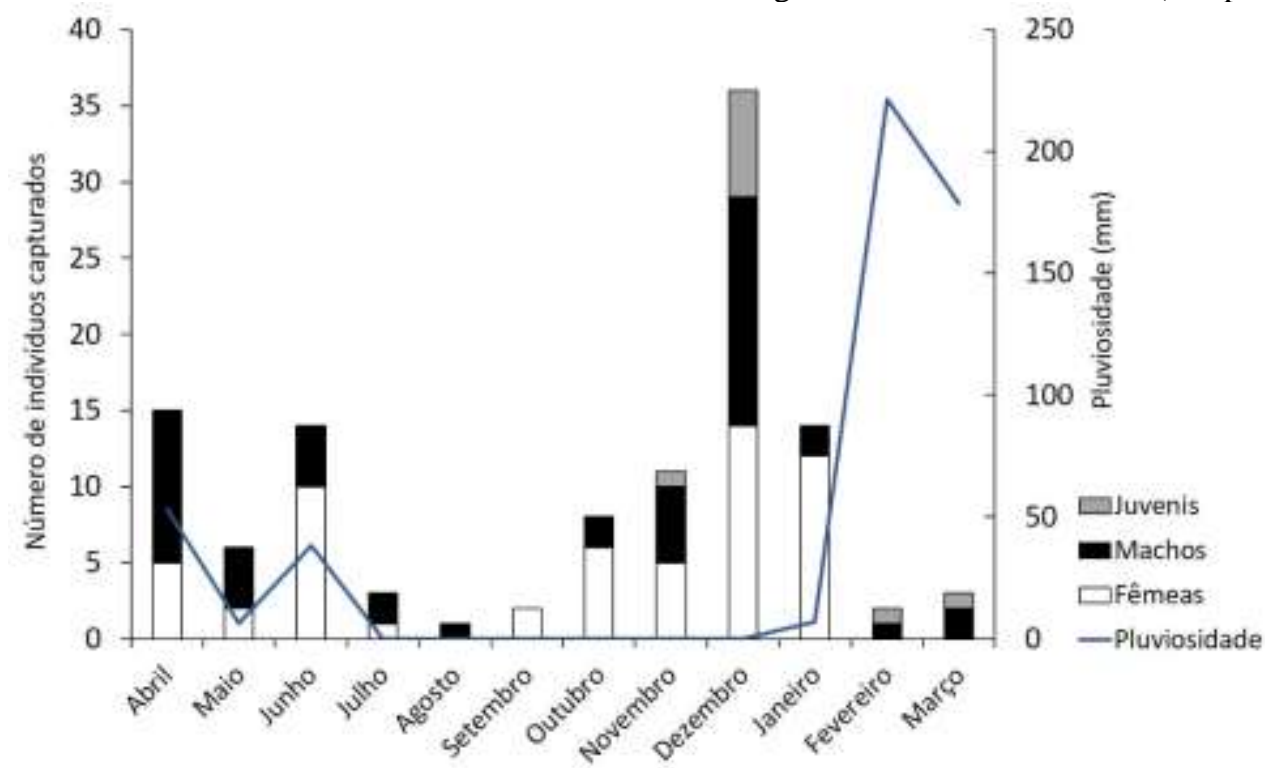

Source: Research data (2017).

Figure 4. Relationship between the number of individuals per class (males, females and juveniles) and capture shifts of Phrynops geoffroanus at Fazenda Tamanduá, PB-Brazil.

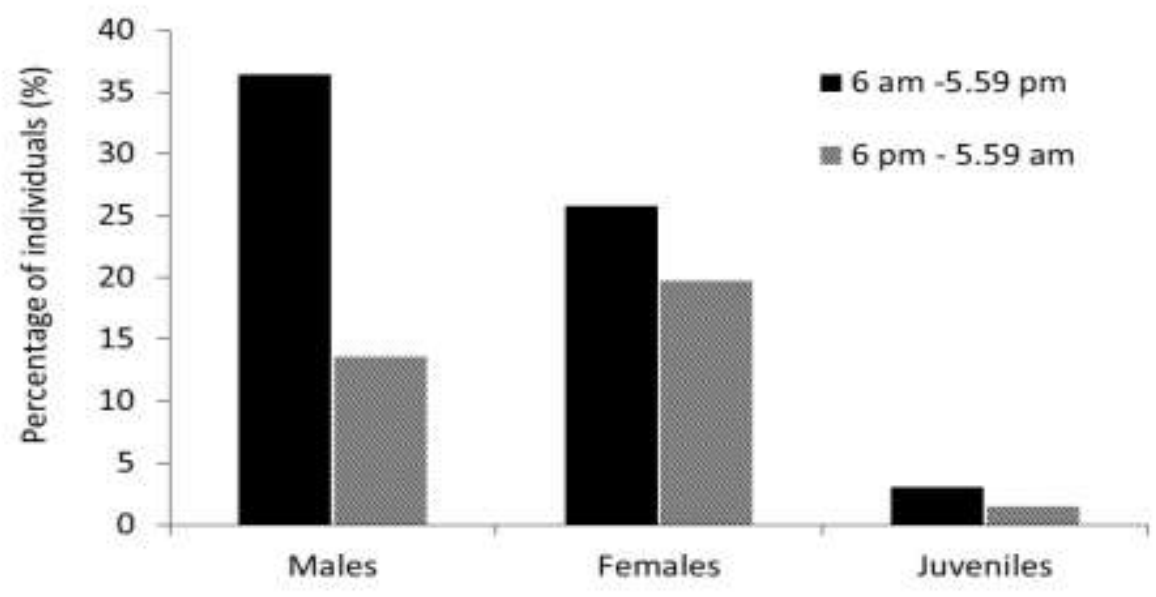

Source: Research data (2017).

Most of the captured individuals, both males and females and juveniles were captured during the day, although there was no significant difference between capture shifts $\left(\mathrm{F}_{(1,13)}=0,198 ; \mathrm{p}=0,663\right)$. Phrynops geoffroanus is a diurnal species and its activity pattern is influenced by air temperature (Souza, 2004). However, water temperature, especially in warmer areas, can be an important predictor of activity of this species, as found by Lescano et al. (2008) for Hydromedusa tectifera. This statement may explain why there is no difference between the number of individuals captured during day or night.

In natural populations of testudines, differences between the number of male and female individuals are common (Gibbons, 1990; Bujes et al., 2011; Rodrigues \& Silva, 2015). However, the Phrynops geoffroanus population studied did not 
show a significant difference in sex ratio. Similar results were recorded for this species by Moura et al., (2015) in another area of Caatinga and by Souza \& Abe (2001) in southeastern Brazil. Several authors argue that these differences in the proportion of males and females are usually associated with inequality in activity patterns between the sexes, differences in mortality rates between males and females, changes in egg incubation temperature influencing sex determination in some species, or even reflect the use of biased sampling techniques (Bury, 1979; Gibbons, 1990; Vogt, 1980; Fachin-Téran et al., 2003, Pezzuti et al., 2010; Famelli et al., 2011). However, Rueda-Amonacid et al., (2007) mentions that P. geoffroanus populations have a 1: 1 sex ratio as a striking characteristic for the species and that it has genetic determination for sex.

The sampled turtle population is composed mainly of adult individuals. According to Conway-Gomméz (2007) the greater the hunting pressure suffered by testudines living near human communities. This distribution of size classes in the sample population suggests that hunting may not be a depressing element in the study population, but related studies are needed for confirmation.

A low proportion of juveniles was also recorded for P. tuberosus in the work conducted by Rodrigues \& Silva (2015). These authors determine that factors such as low adult mortality, high investment in individual growth, as well as high predation rates of juveniles (Verdon \& Donnely, 2005) may explain this distribution. In southeastern Brazil, P. geoffroanus roosts between February and August (Rueda-Amonacid et al., 2007), and in captivity, births of neonates occur within 115-186 days (Lisboa et al., 2004). However, Vogt (2008) suggests that the incubation period in natural environments should be controlled by ambient temperature and humidity, coordinating diapause and embryonic aestivation (Doody et al., 2001), allowing for a shorter incubation time.

Souza (2004) mentions that hatchlings of P. geoffroanus occur during the rainy seasons in southeastern Brazil (December and January). The presence of favorable environmental conditions in this period (greater number of pools, small lakes and temporary rivers) may explain this synchronized behavior between nesting and hatching (Souza, 2004). For species that breed in the Caatinga, strategies like these may be important reproductive mechanisms, allowing eggs to live in warmer and drier environments, accelerating their development. Although this may explain the appearance of young individuals at the end of the dry season and beginning of the rainy season in the studied area, the reproduction of this species in Caatinga areas is scarce.

Sexual dimorphism can be understood as the result of evolutionary pressures exerted in different ways between the sexes. Morphometric analyses confirmed sexual dimorphism, cited for the species by Ferrara et al. (2017). PCA and MANOVA showed differences in carapace and plastron size and curvature, showing a sexual dimorphism directed towards larger and heavier females than males. Males, on the other hand, have larger tails when compared to females. This size difference between the sexes is generally attributed to sexual selection (Perry \& Mitchell, 2016). The presence of larger females may be a reflection of fertility selection, as larger females may have greater reproductive potential, either in the production of larger litters or the ability to breed more frequently in the same breeding season (Stephens \& Wiens, 2009). On the other hand, this difference may be related to the lack of fighting territory for males (Berry \& Shine, 1980), favoring smaller and more agile males (Perry \& Mitchell, 2016).

Tail length and width are the most constant characteristics for differentiating males and females among turtles (RuedaAmonacid et al., 2007). Males have increasingly larger tails than females, probably to house the penis. However, larger tails may promote reproductive advantages for males during copulation (Moll, 1980).

The estimated density and biomass of Phrynops geoffroanus at Fazenda Tamanduá suggest that this species plays an important role in the aquatic ecosystems of the area studied. The population density and biomass recorded were higher than those found, also in Caatinga, by Moura et al., (2015) (only 9 ind / ha). However, in this study three species were recorded in 
the area (Mesoclemmys tuberculata, Kinosternon scorpioides and Phrynops geoffroanus). As reported for Hydromedusa tectifera in Argentina (Lescano et al., 2008), at Fazenda Tamanduá, P. geoffroanus is the only turtle species recorded in the reservoir studied. This lack of competitors may provide a larger population size in the study area, as intraspecific interactions can act as important population drivers in sympatric species (Dreslik et al., 2005; Lescano et al., 2008). Furthermore, the 1ow recapture rate suggests that the population of this species at Fazenda Tamanduá may be larger than estimated.

On the other hand, in Caatinga areas the temporality of water bodies can influence the density of aquatic species. Although there are other reservoirs in the farm area, the water body studied is the one with the highest capacity and, therefore, the highest hydroperiod. In general, hydroperiod affects the stability and complexity of the environment (Werner et al., 2007), providing a greater supply of refugia and food, and may contribute to the juvenile development and adult survival of $P$. geoffroanus. It is possible that as the smaller bodies dried up, the individuals left these reservoirs in search of new favorable environments, changing the population density and biomass of the sampled reservoir, especially during the drier periods of the year.

Due mainly to the ephemerality of the Caatinga aquatic environments and the unpredictability of rainfall in this biome, the populations of aquatic species show large variations in population and in their biological activities. The behavior of burrowing in the mud found in this study raises a hypothesis that these animals are estivating. Aestivation behavior has been described for Hydromedusa tectifera, another species in the family Chelidae. However, further studies are needed to test this hypothesis raised in this study.

\section{Final considerations}

The population studied shows sexual dimorphism and sex ratio expected for the species. However, this is only a one-off study.

Detailed long-term studies are fundamental to the understanding of these variations in these populations, especially habitat use. Studies addressing reproductive strategies and other ecological aspects of habitat use in free-living individuals can fill several gaps in the natural history of Caatinga testudines.

\section{References}

Alves, A. G. C.; Souto, F. J. B. \& Leite, A. M. 2002. Etnoecologia dos cágados d’água Phrynops spp. (Testudinomorpha: Chelidae) entre pescadores artesanais no açude Bodocongó, Campina Grande, Paraíba, Nordeste do Brasil. Sitientibus série Ciências Biológicas 2(1/2): 62-68.

Batistella, A. M. E.; Vogt, R. C. 2008. Nesting Ecology of Podocnemis erythrocephala (Testudines, Podocnemididae) of the Rio Negro, Amazonas, Brazil. Chelonian Conservation and Biology 7(1): 12-20.

Berry, J. F. \& Shine, R. 1980. Sexual size dimorphism and sexual selection in Turtles (Order Testudines). Oecologia. 44(2): 185- 191.

Brito, E. S. de; Strussmann, C.; Penha, M. F. 2009. Population Structure of Mesoclemmys vanderhaegei (Bour, 1973) (Testudines: Chelidae) in the Cerrado of Chapada dos Guimarães, Mato Grosso, Brazil. Biota Neotropica. 9(4): 245-248.

Bujes, C. S.; Molina, F. B.; Verrastro, L. 2011. Population characteristics of Trachemys dorbigny (Testudines, Emydidae) from delta do Jacuí state park, Rio Grande do Sul, Southern Brazil. South American Journal of Herpetology. 6: 27-34.

Bury, R. B. 1979. Population ecology of freshwater turtles. pp. 571-604. In: M. Harless, M. \& Morlock, M. (eds.). Turtles: Perspectives and Research. New York: John Wiley and Sons.

Chen, T. H. \& Lue, K. Y. 2002. Growth patterns of the yellow-margined box turtle (Cuora flavomarginata) in northern Taiwan. Journal of Herpetology. 36: 201-208.

Conway-Gomez, K. 2007. Effects of human settlements on abundance of Podocnemis unifilis and P. expansa turtles in northeastern of Bolivia. Chelonian Conservation and Biology. 6 (2): 199-205.

Corazza, S. S. \& Molina, F. B. 2004. Biologia Reprodutiva e Conservação ex-situ de Bufocephala vanderhagei (Testudines, Chelidae): Primeiras Observações. Arquivos do Instituto Biológico. 71: 410-412. 
Costa-Neto, E. M. \& Alves, R. R. N. 2010. Zooterapia: os animais na medicina popular brasileira. NUPEEA. Recife.

Doody, J. S.; Georges, A.; Young, J. E.; Pauza, M. D.; Pepper, A. L.; Alderman, R. L. \& Welsh, M. A. 2001. Embryonic aestivation and emergence behaviour in the pig-nosed turtle, Carettochelys insculpta. Canadian Journal of Zoology. 79 (6): 1062-1072.

Dreslik, M. J.; Kuhns, A. R. \& Phillips, C. A. 2005. Structure and composition of a southern Illinois freshwater turtle assemblage. Northeastern Naturalist. 12: 173-186.

Embrapa. 2006. Centro Nacional de Pesquisas de Solos. Sistema brasileiro de classificação de solos. Rio de Janeiro. $2^{\text {a }}$ ed. $306 \mathrm{p}$.

Fachín-Téran, A., Vogt, R. C., Thorbjarnarson, J. B. 2003. Estrutura populacional, razão sexual e abundância de Podocnemis sextuberculata (Testudines, Podocnemididae) na Reserva de Desenvolvimento Sustentável Mamirauá, Amazonas, Brasil. Phyllomedusa. 2: 43-63.

Fachín-Terán, A. E. \& Vogt, R. C. 2004. Estrutura populacional, tamanho e razão sexual de Podocnemis unifilis (Testudines, Podocnemidae) no rio Guaporé (RO), norte do Brasil. Phyllomedusa. 3(1): 29-42.

Fagundes, C. K. \& Bager, A. 2007. Ecologia reprodutiva de Hydromedusa tecifera (Testudines: Chelidae) no sul do Brasil. Biota Neotropica. 7(2): 179-184.

Famelli, S., Bertoluci, J., Molina, F. B., Matarazzo-Neuberger, W. M. 2011. Structure of a population of Hydromedusa maximiliani (Testudines, Chelidae) from Parque Estadual da Serra do Mar, an Atlantic Rainforest Preserve in Southeastern Brazil. Chelonian Conservation and Biology 10: 132-137.

Ferrara, C. R.; Fagundes, C. K.; Morcatty, T. Q. \& Vogt, R. C. 2017. Quelônios Amazônicos: guia de identificação e distribuição. Manaus: WCS.

Forero-Medina, G.; Castaño-Mora, O. V.; Cárdenas-Arevalo, G. \& Medina-Rangel, G. F. 2013. Família Chelidae. In: páez, v.p.; morales-betancourt, a.; lasso, c.a.; Castaño-Mora, O. V. \& Bock, B .C (eds.). Biología y Conservación de las Tortugas Continentales de Colombia. Serie Recursos Hidrobiologicos y Pesqueros Continentales de Colombia. Bogotá, Instituto de Investigación de Recursos Biologicos Alexander von Humboldt.

Kennet, R. 1996. Growth models for two species of freshwater turtle, Chelodina rugosa and Elseya dentate, from the wet-dry tropics of northern Australia. Herpetologia. 52: 383-395.

Lescano, J.; Leynaud, G. \& Bonino, M. 2008. Density, population structure and activity pattern of Hydromedusa tectifera (Testudines-Chelidae) in a mountain stream of Córdoba province, Argentina. Amphibia-Reptilia. 29(4), 505-512.

Lisboa, C. S.; Chinen, S. \& Molina, F.B. 2004. Influência da temperatura no período de incubação dos ovos de Phrynops geoffroanus (Testudines, Chelidae). Arquivos do Instituto Biológico 71: 390-393.

Marques, T. S.; Lara, N. R. F.; Bassetti, L. A. B.; Ferronato, B. O.; Malvásio, A. \& Verdade, L. M. 2013. Population structure of Mesoclemmys vanderhaegei (Testudines, Chelidae) in a silvicultural system in southeastern Brazil. Herpetology Notes. 6:179-182.

Martins, F. I. \& Souza, F. L. 2008. Estimates of growth of the Atlantic rain forest freshwater turtle Hydromedusa maximiliani (Chelidae). Journal of Herpetology 42:54-60.

Miorando, P. F.; Giarrizzo, T. \& Pezzuti, J. C. B. 2015. Population structure and allometry of Podocnemis unifilis (Testudines, Podocnemididae) in a protected area upstream Belo Monte dam in Xingu River, Brazil. Anais da Academia Brasileira de Ciências. 87(4): 2067-2079

Moro, M. F.; Nic Lughadha, E. de; Araújo, F. S. \& Martins, F. R. 2016. A Phytogeographical Metaanalysis of the Semiarid Caatinga Domain in Brazil. The Botanical Review. 82: 91-148.

Moura, C. C. de M.; Moura, G. J. B. de; Lisboa, E. B. F. \& Luz, V. L. F. 2014. Distribuição geográfica e considerações ecológicas sobre a fauna de Testudines da Região Nordeste do Brasil. Sitientibus: Série Ciências Biológicas. 14

Moura, C. C. de M.; Moura, G. J. B. de; Chaves, L.; Muniz, S.; Veja, E. S. \& Junior, V. 2015. Demography, sex ratio, and sexual dimorphism of Testudines in Araripe Bioregion, Ceará, Northeastern Brazil. North-Western Journal of Zoology. 11(2): 204-212.

Passos Filho, P. de B.; Chaves, L. da S.; Carvalho, R. A.; Pilatti, P.; d’Assunção, M. M. \& Prado Neto, J.G. do. 2015. Fauna Ilustrada da Fazenda Tamanduá.415 pp.

Perry, S. M.; Mitchell, M. A. 2016. Reproductive medicine in freshwater turtles na land tortoises. Veterinary Clinics: Exotic Animals.

Pezzuti, J. C. B.; Pantoja-Lima, J.; Félix-Silva, D \& Begossi, A. 2010. Uses and taboos of turtles and tortoises along Rio Negro, Amazon basin. J Ethnobiol. 30(1): $153-168$

Primack, R. B. 2012. A primer of conservation biology. 5 ed. Sunderland, MA: Sinauer Associates, 363 pp.

Rodrigues, J. F. M. \& Silva, J.R.F. 2015. Population structure, activity, and sex ratio of Phrynops tuberosus (Testudines: Chelidae) em Caatinga, Brazil. NorthWestern Journal of Zoology. 11(1): 127-132.

Rueda-Almonacid, J. V.; Carr, J. L.; Mittermeir, R. A.; Rodriguez-Mahecha, J. V.; Mast, R. B.; Vogt, R. C., Rhodin, A. G. J.; Ossa-Velásquez, J.; Rueda, J. N. \& Mittermeir C. G. 2007. Las tortugas y los cocodrilianos de los países andinos del trópico. Serie de guías tropicales de campo No 6. Conservación Internacional. Editorial Panamericana, Formas e Impresos. Bogotá, Colombia. 538 pp.

Santana, D. O. 2012. Dieta, dinâmica populacional, e ectoparasitas de Phrynops geoffroanus (Schweigger, 1812) (Testudinata, Chelidae) do Baixo São Francisco, Poço Redondo, SE. Dissertação apresentada no Programa de Pós-Graduação em Ecologia e Conservação da Universidade de Sergipe, p. 1-109. 
Research, Society and Development, v. 10, n. 7, e9510715154, 2021

(CC BY 4.0) | ISSN 2525-3409 | DOI: http://dx.doi.org/10.33448/rsd-v10i7.15154

Santana, D. O. 2016. Autoecologia Comparativa de duas espécies de quelônios (Phrynops geoffroanus e Mesoclemmys tuberculata) em áreas de Caatinga e Mata Atlântica no Nordeste do Brasil. Tese apresentada no Programa de Pós-Graduação em Ciências Biológicas. p. 212.

Souza, F. L. 2004. Uma revisão sobre padrões de atividade, reprodução e alimentação de cágados brasileiros (Testudines, Chelidae). Phyllomedusa. 3(1): 1-13.

Souza, F. L. \& Abe, A. S. 2001. Population Structure and Reproductive Aspects of the Freshwater Turtle, Phrynops geoffroanus, Inhabiting an Urban River in Southeastern Brazil. Studies on Neotropical Fauna and Environment. 36(1): 57-62.

Souza, F. L. \& Molina, F. B. 2007. Estado atual do conhecimento de Quelônios no Brasil, com ênfase para as espécies não amazônicas. In: Nascimento, L.B. \& Oliveira, M.E. (eds). Herpetologia no Brasil (Vol. 2, pp. 264-277). Sociedade Brasileira de Herpetologia. Belo Horizonte.

Spencer, R. J. 2002. Growth patterns of two widely distributed freshwater turtles and a comparison of common methods used to estimate age. Australian Journal of Zoology. 50: 477-490.

Stephens, P. R. \& Wiens, J. J. 2009. Evolution of sexual size dimorphisms in emydid turtles: ecological dimorphism, Rensch's rule, and sympatric divergence. Evolution. 63:910-925.

Verdon, E. \& Donnelly, M. A. 2005. Population Structure of Florida Box Turtle (Terrapene carolina bauri) at the Southernmost limit of their range. Journal of Herpetology. 39: 572-577.

Vogt, R. C. 1980. New methods for trapping aquatic turtles. Copeia 2: 368-371.

Vogt, R. C. 2008. Tartarugas da Amazônia. Lima: Gráfica Biblos, 104p.

Werner, E. E.; Skelly, D. K.; Relyea, R. A. \& Yurewicz, K. L. 2007. Amphibian species richness across environmental gradients. Oikos. 116:1697-1712.

Willemsen, R. E. \& Hailey A. 2003. Sexual dimorphism of body size and shell shape in European tortoises. Journal of Zoology, London. 260, $353-365$.

Zar, J. H. 2010. Biostatistical Analysis. 5th Edition, Prentice-Hall/Pearson, Upper Saddle River, xiii, 944 p. 